\title{
THE GUARANTEES OF LABOUR RIGHTS IN THE PROCESS OF WORK OF WOMEN AND PERSONS ENGAGED IN PERFORMANCE OF FAMILY DUTIES
}

\author{
Dinra Atajanova, \\ Senior teacher at Tashkent State University of Law
}

E-mail: aranid87@rambler.ru m.phone: +999890 934-21-00

\section{Crossref} http://dx.doi.org/10.26739/2433-202x Issue DOI http:/ /dx.doi.org/10.26739/2433-202x-2017-10-10 Article DOI http://dx.doi.org/10.26739/2433-202x-2017-10-10-2

\begin{abstract}
In this article is spoken and analyzed normative-legal sources of transfer to other work of women and persons engaged in performance of family duties. As the title implies the article describes guarantees in process of labour for Social science and humanities

D. Atajanova
\end{abstract}


women and persons engaged in performance of family duties. It draws attention todifferent practical problems about the theme. The author puts forward her offers for improving legislation.

Keywords: women and persons engaged in performance of family duties, pregnant women, transfer to other work, work time, medical examination, attestation.

In the process of labor relations, women and persons engaged in the performance of family duties are provided with a number of guarantees. These guarantees are observed in the process associated with the transfer to another job, guarantee payments, working time, as well as ensuring the preservation of the place of work.

The rules established at the conclusion of the employment contract must be observed even with the further performance of the employee's duties. The invariability of the terms of the contract is the basis of the legal norms governing the issues of transferring to another job ${ }^{1}$.

In the opinion of A.Inoyatov in the conditions of a market economy, in practice it is extremely important to be aware of the content of legal norms relating to changes in working conditions, transfer to another job with the aim of providing social, economic and legal protection in the sphere of labor relations ${ }^{2}$.

In connection with the emergence of various circumstances after the conclusion of the employment contract there is a need to make changes to it. A change in an employment contract is generally understood as a temporary or permanent transfer of an employee to another job. Women are often forced to temporarily move to another job due to physiological changes in the body during pregnancy. According to Part 4 of Art. 96 of the Labor Code of the Republic of Uzbekistan, the basis for issuing an order for the temporary transfer to another job of pregnant women and women with children under the age of two is their application and medical report. ${ }^{3}$

\footnotetext{
1 Labour law of Russia. The textbook for higher education institutions. editor-in-chief Dr.Sc,prof.R.Z.Livshits and Dr.Phd,. prof. Yu.P.Orlovskiy. -M.:INFRA M-NORMA, 1998. -P.116 (In russian)

2 A.Inoyatov. The labour of the Republic of Uzbekistan. The textbook for higher education institutions -T.: the editorial office «The world of economy and law», 2002. -P.146

${ }^{3}$ Sheets of Oliy Majlis of the Republic of Uzbekistan, 1996, the application to No. 1

Social science and humanities

D. Atajanova
} 
In connection with the emergence of various circumstances after the conclusion of the employment contract there is a need to make changes to it. A change in an employment contract is generally understood as a temporary or permanent transfer of an employee to another job. Women are often forced to temporarily move to another job due to physiological changes in the body during pregnancy. According to Part 4 of Art. 96 of the Labor Code of the Republic of Uzbekistan, the basis for issuing an order for the temporary transfer to another job of pregnant women and women with children under the age of two is their application and medical report.

This fact is reflected in Art. 226 of the Labor Code, which states that pregnant women in accordance with the medical conclusion are reduced production standards, service standards or they are transferred to an easier or excluding the impact of unfavorable production factors work with the preservation of the average monthly earnings from previous work. However, Art. 227 of the Labor Code does not provide for the obligation to provide medical advice when transferring women with children under the age of two years in the event that it is impossible to perform the former work for easier or excluding the impact of unfavorable production factors, work with the preservation of the average monthly earnings from previous work until the child reaches the age of two years.

That is, in 227 art. The Labor Code does not provide a generally established medical report for pregnant women and women who have a child under the age of two specified in art. 96 of the Labor Code. We believe that the norms of these articles of the Labor Code should be harmonized. Since an expert or other person who wants to become acquainted with the norms concerning the work activity of women and persons engaged in the performance of family duties may not pay attention to Art. 96 of the Labor Code.

According to Art. 228 of the Labor Code of the Republic of Uzbekistan it is not allowed to attract pregnant women and women with children under the age of fourteen (invalids under sixteen) to night work, overtime work, weekend work and travel on business, without their consent. At the same time, pregnant women and women with children under three years of age Social science and humanities

D. Atajanova 
can be involved in night work if there is a medical certificate confirming that such work does not endanger the health of the mother and the child.

In the labor legislation of the Republic of Uzbekistan, there is no rule prohibiting or allowing the direction of women or persons engaged in the performance of family duties to improve their qualifications. In fact, sending pregnant women to improve their skills seems unreasonable. Because, a pregnant woman in the shortest time goes on maternity leave, and then on leave to care for the child. Naturally, even if a woman undergoes advanced training before applying her skills, it will take time. The unsettledness of this issue to date has not been so "important". The Resolution of the Cabinet of Ministers "On measures to organize retraining and upgrading the skills of leading and pedagogical staff of higher educational institutions" of August 20, 2015, No. $242^{4}$, placed the resolution of this issue on the agenda. As indicated in clause 12 of the Regulation On the courses of retraining and upgrading of the leading and pedagogical staff of higher educational institutions approved by this Decree, the leading and pedagogical cadres of higher educational institutions that have not passed the certification based on the results of training at retraining and advanced training courses are required within one year to re-pass the certification based on the results of the next course of retraining and advanced training on a fee basis for the relevant or related purpose education (specialty). In case of repeated failure of pedagogical staff of higher educational institutions to attest attestation on the results of training at retraining and advanced training courses or failure to attend repeated courses of retraining and in-service training within the established period, in the main place of work with these workers, in accordance with the established procedure, the employment contract is terminated within two months, Depending on the term of the concluded labor contract and the deadline for the completion of the period of competitive substitution of pedagogical (item 13 of the Regulations).

The referral for retraining and advanced training of working pregnant women and women with a child under the age of three years following the

${ }^{4}$ Collection of the legislation of the Republic of Uzbekistan, 2015, No. 33, Art. 442, No. 52, Art. 646 
results of training for advanced training, as provided in this regulatory legal document, is considered to be inexpedient. Since according to Art. 227 of the Labor Code of the Republic of Uzbekistan, termination of the employment contract with pregnant women and women with children under the age of three years, at the initiative of the employer is not allowed. Certification is a circumstance determining the qualification of the employee, and for this reason the employment contract is terminated at the initiative of the employer. In this regard, to ensure the labor rights of women and persons engaged in the performance of family responsibilities, it is necessary to find a solution to the existing problem.

The law does not regulate all types of time associated with the implementation of socially useful activities (for example, entrepreneurial activity, sometimes creative activity). Only activities carried out on the basis of an employment contract are governed by law. ${ }^{5}$ When it comes to guarantees related to the labor process, it is imperative to focus on the institute of working time, as labor relations take place during the working time.

According to A. Inoyatov, the purpose of the legal regulation of working time is to protect the working conditions of employees at the highest level and at the same time, the full use of working time and its careful use ${ }^{6}$.

According to Y.Tursunov and M.Usmanova, the correct definition and maintenance of the physiological and social boundaries of working time is carried out with the aim of protecting the physical and mental health of workers, preventing their premature aging, contracting diseases, preventing their labor abilities from decreasing, and also giving The opportunity for the employer to achieve the necessary economic results ${ }^{7}$.

Agreeing with the opinions of the authors and basing on the fact that the employer has the right to dispose of his powers only within the limits of

\footnotetext{
${ }^{5}$ Molodsov M.V., Golovina S.Yu. Labour law of Russia: The textbook for higher education institutions. -M.: NORMA, 2003. -P. (In russian)

${ }^{6}$ A.Inoyatov. The labour of the Republic of Uzbekistan. The textbook for higher education institutions -T.: the editorial office «The world of economy and law», 2002. -P.209

7 Y.Tursunov, M.A.Usmonova. Labour law. Textbook. - T.: Publishing house of TSIL . 2006. - P.130 (In uzbek)

Social science and humanities

D. Atajanova
} 
working time, it can be said that the correct establishment of working hours at the enterprise, we believe, prevents such "unpleasant" cases as disciplinary punishment for the employee, or termination with him an employment contract (in cases of systematic violation or a single gross violation).

In accordance with Art. 116 of the Labor Code of the Republic of Uzbekistan to certain categories of workers, taking into account their age, health status, working conditions, the specifics of labor functions and other circumstances, in accordance with legislative and other normative acts on labor, as well as the terms of the employment contract, , and this category of persons also includes women who have children under the age of three and who work in institutions and organizations financed from the budget. In addition, according to Art. 118 of this code to certain categories of workers (medical workers, teachers and others) whose work is associated with increased emotional, mental, nervous tension, that is, a special nature, the duration of working time is established no more than thirty-six hours a week.

Taking into account that the majority of medical and pedagogical workers are women, we consider it necessary to dwell on this aspect separately. The implementation of this norm in law enforcement practice can be seen within the working time of medical workers. The working time of doctors is established on a legal basis, usually from morning to lunch time, and also from lunch to evening, based on the hours of reception. However, it is impossible to call the establishment of working hours for teachers in a clock well organized. For example, if a teacher working in a higher education institution has classes for two shifts, his first pair starts at 8:30, and the other couple in some cases on the same day starts at 16:30 and ends at 17:50. It is obvious that the norm of the 36-hour work week (6 hours a day) is violated when determining the schedule of teachers' classes. The observation of such cases, when establishing a 35-hour work week, naturally leads to violation of the labor rights of working women with a child under the age of three (financed from the budget). We believe that in these cases the employer must follow the guarantees regarding working hours provided for in the labor legislation. 
The labor legislation gives the right to pregnant women to choose only part-time work without the employer's obstacle. However, in some cases, related to pregnancy, in our opinion, additional guarantees are required during the working time. For example, pregnant women every month should undergo a regular check-up at local polyclinics. In this case, working pregnant women are often indifferent to their health, postpone the passage of a medical examination, because they are not given a separate "permission". Consequently, in many cases there are circumstances that are harmful to the health of the mother and child. The Labor Code of the Russian Federation (Article 254) ${ }^{8}$ and the Labor Code of the Kyrgyz Republic (art. 306) ${ }^{9}$ establish that in the case of pregnant women passing a dispensary examination, they are exempted from work while maintaining their wages. During the study of a number of collective agreements, we met this guarantee in the collective agreement of the joint venture "GM Uzbekistan" for 2017 - 2019. In our opinion, this guarantee should be provided for in the Labor Code of the Republic of Uzbekistan.

We are aware that the termination of the employment contract on the initiative of the employer with pregnant women and women having a child under the age of three is not allowed. For this reason, pregnant women and women with a child under the age of three do not pass the certification, even if they are attested, its result, whether positive or negative, is not the basis for termination of the employment contract at the initiative of the employer with this category of employees. This guarantee is reflected in the regulatory legal acts on attestation in various fields.

However, despite this, in practice, there are often cases associated with this situation. It should be noted that during a childcare leave, a woman cares for her child and does not develop her skills and abilities by profession. In this case, women immediately after the leave to take care of the child naturally do not pass the certification. This is established in the regulatory documents on attestation in various fields, in particular the Regulation "On

8

http://www.consultant.ru/document/cons_doc_LAW_34683/239ad77ba34266b365b3706e9dafc365b52f3bcc ${ }^{9} \mathrm{http}: / /$ online.adviser.kg/Document/?link_id=1000852521

Social science and humanities

D. Atajanova 
the procedure for certification of engineering and technical staff in the system of the national television and radio company of Uzbekistan"10, in the Regulation "On the Qualification Commission of Health System Managers under the Ministry of Health of the Republic of Uzbekistan"11, and Also in the Regulation "On the approval of the criteria for assessing the results of attestation of pedagogical staff in pre-school, general secondary, secondary special, professional and public-school educational institutions".12 In accordance with this act, in addition to pregnant women and women with a child under the age of three years, women are not allowed to be certified for one year after the childcare leave. We believe that this norm should be reflected in the Labor Code of the Republic of Uzbekistan. In our opinion, this circumstance corresponds to the principles of social justice. The reason for this is that currently in the period of high-speed information, the professional capabilities of a woman are different from those of active workers, and the sudden evaluation of a woman after a three-year break in many cases can serve her detriment.

The legislation in some areas establishes the procedure for recruitment on a competitive basis. Among them there are also pedagogical cadres of higher educational institutions. According to the Regulation "On the Procedure for Admission of Pedagogical Workers to Higher Educational Institutions on a Competitive Basis"13, the aim of the competition is to create and provide a competitive environment for selecting the most qualified pedagogical staff with profound professional knowledge and scientific achievements, possessing creative, scientific potential, high intellectual abilities and moral qualities worthy of training specialists at the level of the requirements of the National Program for training.

According to paragraph 9 of this Regulation, the competition is not announced for posts occupied by pregnant women, as well as women with children under the age of three. However, taking into account that the

\footnotetext{
${ }_{10}$ Collection of the legislation of the Republic of Uzbekistan, 2009, No. 19-20, Art. 235

${ }_{11}$ Collection of the legislation of the Republic of Uzbekistan, 2007, No. 43, Art. 432

12 Collection of the legislation of the Republic of Uzbekistan, 2016, No. 15, Art. 146

${ }^{13}$ Collection of the legislation of the Republic of Uzbekistan, 2006, No. 6-7, Art. 36 
competition takes into account the report of the person applying for the position on previous scientific and pedagogical, methodological, educational and other works, it would be advisable to announce a competition for positions occupied by pregnant women and women with a child under the age of three years after leave for child care, after one year of continuous work.

Because, because a woman does not work during the leave to take care of the child, she does not perform scientific and pedagogical, methodological, educational activities, and another candidate who carried out the labor activity will have a result. During the voting, the activity of a woman who has just left a childcare leave can be assessed as unsatisfactory and this, in turn, will lead to the termination of the employment contract. In accordance with clause 26 of this Regulation, persons who did not participate in the competition for positions previously held by them, as well as those who did not submit applications for participation in the tender, terminate the employment contract within the terms determined by the rector of the higher educational institution (usually after graduation semester, year) in connection with the failure to compete for a new term or refusal to participate in the competition, in accordance with labor law. For this reason, during the accelerated reforms and news, it is necessary to consider this issue in order to create opportunities for adaptation to women and persons engaged in the performance of family responsibilities after the leave to take care of the child.

Most of our life is spent at work places, as the basis of human activity is labor. The legal reflection of the guarantees provided for in the labor legislation in practice will serve to increase the efficiency of workers, hence, to increase the efficiency of labor. 


\section{References}

1. Labour law of Russia. The textbook for higher education institutions. editor-in-chief Dr.Sc,prof.R.Z.Livshits and Dr.Phd,. prof. Yu.P.Orlovskiy. M.:INFRA M-NORMA, 1998. -P.116 (In russian)

2. A.Inoyatov. The labour of the Republic of Uzbekistan. The textbook for higher education institutions -T.: the editorial office «The world of economy and law», 2002. -P.146

3. Sheets of Oliy Majlis of the Republic of Uzbekistan, 1996, the application to No. 1

4. Collection of the legislation of the Republic of Uzbekistan, 2015, No. 33, Art. 442, No. 52, Art. 646

5. Molodsov M.V., Golovina S.Yu. Labour law of Russia: The textbook for higher education institutions. -M.: NORMA, 2003. -P. (In russian)

6. A.Inoyatov. The labour of the Republic of Uzbekistan. The textbook for higher education institutions -T.: the editorial office «The world of economy and law», 2002. -P.209

7. Y.Tursunov, M.A.Usmonova. Labour law. Textbook. - T.: Publishing house of TSIL . 2006. - P.130 (In uzbek)

8. http://www.consultant.ru/document/cons_doc_LAW_34683/239ad77 ba34266b365b3706e9dafc365b52f3bcc

9. http://online.adviser.kg/Document/?link_id=1000852521

10. Collection of the legislation of the Republic of Uzbekistan, 2009, No. 19-20, Art. 235

11. Collection of the legislation of the Republic of Uzbekistan, 2007, No. 43, Art. 432

12. Collection of the legislation of the Republic of Uzbekistan, 2016, No. 15, Art. 146

13. Collection of the legislation of the Republic of Uzbekistan, 2006, No. 6-7, Art. 36 